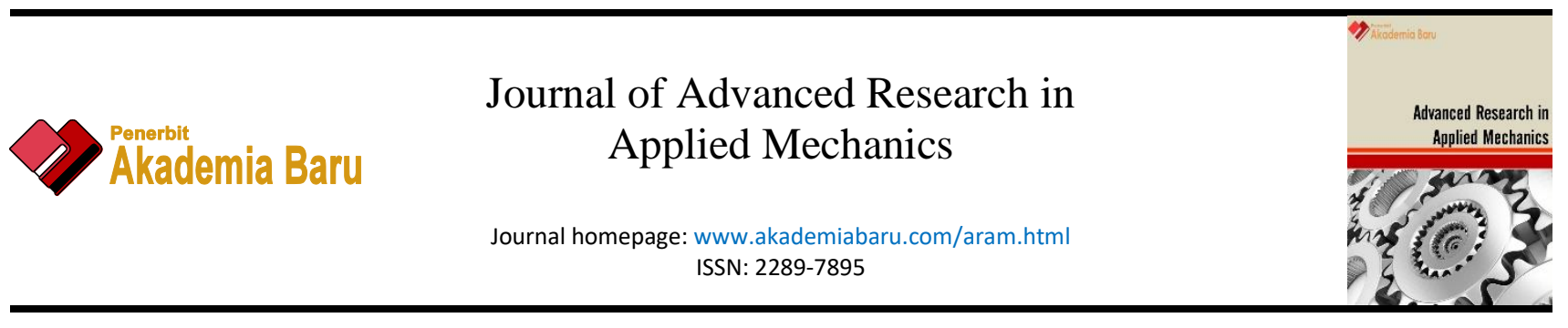

\title{
Automated Electrostatic Discharge Self-Audit System in Semiconductor Industry
}

\author{
Puvanieshvaran Ampanatham ${ }^{1}$, Hazilah Mad Kaidi1, ${ }^{1,}$, Shamsul Sarip ${ }^{1}$ \\ 1 Department of Engineering, Razak Faculty of Technology and Informatics, Universiti Teknologi Malaysia, 54100 Kuala Lumpur, Malaysia
}

\begin{abstract}
Electrostatic Discharge (ESD) is a well-known control process in semiconductor industries, military, medical industry, aerospace industry, oil and gas industry and so on. ESD means the collision between two elements with influence of humidity will create static charges. The static charge will be measured in voltage/inch and then compared with the sensitivity of the Electrostatic Discharge Sensitive (ESDS) items to avoid electronics malfunctions and latent damage to the items. Human Body Model (HBM) tests are done periodically based on the semiconductor industry and customer requirements. The new revision recommends the HBM test done on daily basis for the high control. Common control for HBM involve the footwear test and wrist strap test which done manually. The tighten control for daily test is not possible for manual method of testing, so the idea of converting to automatic testing system are designed and implemented. This design will able to do ESD HBM test daily before entering production floor and the same time adding value as monitoring system as well. The HBM Model test will emphasis hundred percent accuracy of employees testing their ESD attires and also improve the common manual system to an automated system. Implementation of this system will ensure product quality and also minimize the risk of ESD events occurring in semiconductor industry.
\end{abstract}

Keywords:

Electrostatic Discharge, Human Body

Voltage, Audit System

Copyright $\odot 2020$ PENERBIT AKADEMIA BARU - All rights reserved

\section{Introduction}

Electrostatic Discharge (ESD) control is a vital requirement in semiconductors industries and there are many activities are carried out many associations to identify the cause of ESD events on the Electrostatic Discharge Sensitivity (ESDS) items such as components, printed circuit board assembly (PCBA), inductors and so on. The common cause for the event is Human Body Model (HBM) effects which discussed by author [1-2] and the common control that in current implementation and approved based on the global ESD association are described by author [3-7].

Control HBM is the important element where controlled by using proper ESD protection attire such as ESD Shoe and ESD Wrist Strap which are commonly in use at many semiconductor industries. The daily audit system is required to maintain the functionality of these attires and manual way of self-audit is not suitable, so the automated system is introduced. The idea is to install the ESD test application inside the turnstile gate so the attires are tested every day.

\footnotetext{
* Corresponding author.

E-mail address: hazilah.kl@utm.my

https://doi.org/10.37934/aram.65.1.2731
} 
The ESD control programs have played a vital role to avoid most of the ESD related failures; however statistics still show the failure cases happen in well controlled EPA production floor. From the statistic of ten years it shows that current ESD program are good but not good enough to identify and solve all ESD related problems that occurs in the electronic assembly production floor. The current ESD program is not fully able to prevent the ESD/EOS events, and the most common events that happen are related to HBM because the $50 \%$ of the failure recorded under ESD/EOS are affecting Integrated Circuits (IC) which commonly happens by human body charge induced. Controlling the HBM on semiconductor sites will bring much proven control for the site ESD programs by author [810], author [13-14] and author [12] describing the method to select and appropriate HBM control attires to control ESD events occurrences.

\section{ESD Self-Audit System}

The design of footplate for testing the ESD Shoe and design of input jack box for testing the wrist strap are illustrated using SketchUp and handover to appointed vendor for physical designing. The design of footplate meets the criteria to fulfill the weight and foot size of people and the input jack box are designed as per the wrist strap standard diameter application such as shown in Figure 1 and Figure 2.

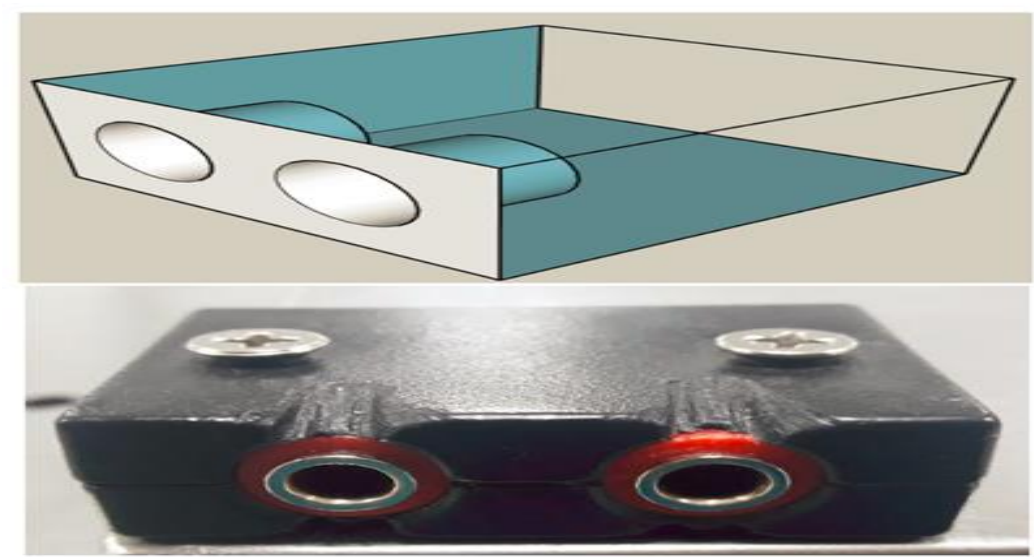

Fig. 1. The illustrated design and custom design for wrist strap testing

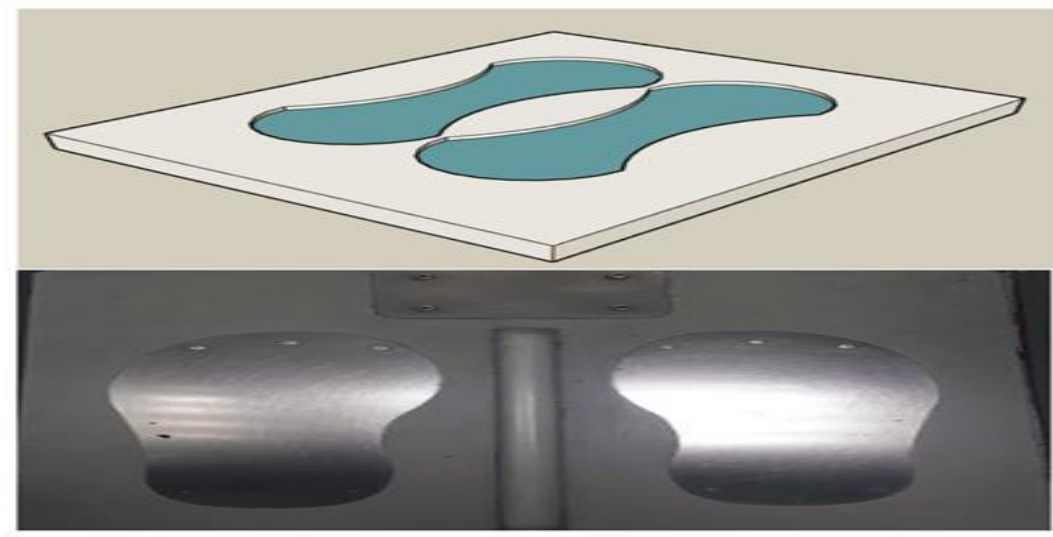

Fig. 2. The illustrated design and custom design for footwear testing 
The next process is the installation of these two items into the existing turnstile and also selecting the suitable software that can meet both security and ESD card scanning. The software selected for this process is Captain Green and tester is Megalin where both are Taiwan technology. The system need to combine with the turnstile gate so that only passed test are able to enter the production floor. The full installed turnstile system shown in Figure 3.

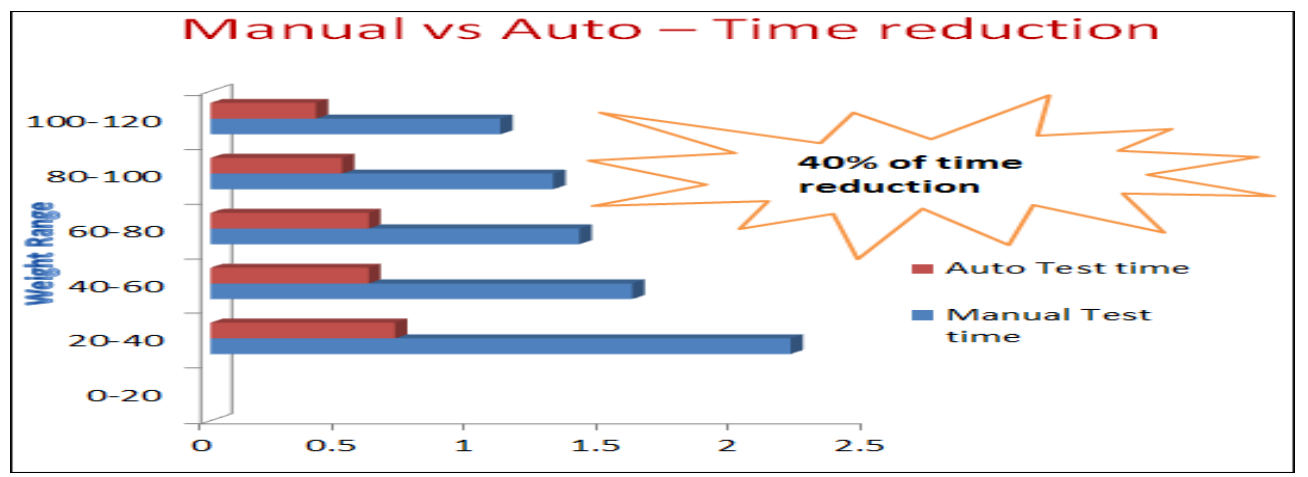

Fig. 3. Automatic vs manual test time

The ESD self-audit system installed turnstile will be connected to the Captain Green software which is the Megalin tester's custom designed software to capture the test data value. This process will need IT support and the organization approval to use their server and Ethernet access. This system will able to do HBM test for footwear and wrist strap at the same time.

\section{Results and Discussion}

The system's hardware (footplate and wrist strap input jack) is design to meet all criteria of employees, especially the one physically challenged personal and also over weight employees. After the implementation the system on single turnstile gate, then the whole process is tested, validated and then analyzed, before the implementation for all existing turnstile gates. The advantages and disadvantages of the system studied and continuous improvement applied at those areas needed.

\subsection{Time saving}

This system able to reduce the time of total sample of 1000 employees, at 40 percentage time reducing with 100 percentage of test done by all employees. This tackles two issues at the same point, ensure quality of test audit compliance are fulfilled and time to do this test are reduced. Figure 3.0 shows the statistical of auto and manual system comparison as weight taken as sample measurement.

\subsection{The comparison between manual and automated system}

The implementation of automated system not only able to reduce time and increase test percentage but also benefits more as shown in Table 1. 


\section{Table 1}

Comparison between automated and manual test system

\begin{tabular}{|c|c|c|c|c|}
\hline SYSTEM & $\begin{array}{l}\text { MANUAL ESD } \\
\text { SELF-AUDIT } \\
\text { SYSTEM }\end{array}$ & $\begin{array}{c}\text { AUTOMATED } \\
\text { ESD SELF-AUDIT } \\
\text { SYSTEM }\end{array}$ & Conclusion & Advantage \\
\hline \multirow[t]{2}{*}{ Design } & $\begin{array}{l}\text { Able to bare only } \\
\text { max up to } 120 \mathrm{Kg} \\
\text { only }\end{array}$ & $\begin{array}{l}\text { Able to bare up to } \\
200 \mathrm{Kg}\end{array}$ & $\begin{array}{l}\text { More convenient } \\
\text { for large size } \\
\text { employees }\end{array}$ & $\begin{array}{l}\text { No need to } \\
\text { custom new } \\
\text { design for certain } \\
\text { employees }\end{array}$ \\
\hline & Single plate planar & $\begin{array}{l}\text { Double footwear } \\
\text { planar }\end{array}$ & $\begin{array}{l}\text { Both shoe test can } \\
\text { be done together }\end{array}$ & Time saving \\
\hline Test method & $\begin{array}{l}\text { Using portable } \\
\text { Resistance Meter, } \\
\text { limit up to } 2 \text { decimal } \\
\text { points }\end{array}$ & $\begin{array}{l}\text { Using integrated } \\
\text { system (Megalin) } \\
\text { and software, test } \\
\text { records up to } 5 \\
\text { decimal points }\end{array}$ & $\begin{array}{l}\text { Automated system } \\
\text { capturing most } \\
\text { persistence result }\end{array}$ & $\begin{array}{l}\text { Persistence result } \\
\text { help for better } \\
\text { data analysis and } \\
\text { error proofing }\end{array}$ \\
\hline $\begin{array}{l}\text { Employees } \\
\text { Feedback of } \\
\text { employees }\end{array}$ & $\begin{array}{l}\text { Not preferred } \\
\text { because many } \\
\text { limitation and not a } \\
\text { compulsory test } \\
\text { process for every } \\
\text { entry }\end{array}$ & $\begin{array}{l}\text { Easy and } \\
\text { comfortable for } \\
\text { them as no skip } \\
\text { process }\end{array}$ & $\begin{array}{l}\text { Help employees to } \\
\text { save time and } \\
\text { money ( no salary } \\
\text { deduction due to } \\
\text { miss self-audit) }\end{array}$ & $\begin{array}{l}\text { Employees are } \\
\text { happier and also } \\
\text { learn about the } \\
\text { importance of } \\
\text { ESD. }\end{array}$ \\
\hline $\begin{array}{l}\text { Management } \\
\text { Review }\end{array}$ & $\begin{array}{l}\text { Many process of } \\
\text { documentation and } \\
\text { monitoring for } \\
\text { compromise the } \\
\text { customers regarding } \\
\text { ESD control on site. }\end{array}$ & $\begin{array}{l}\text { Impressed with } \\
\text { automated system } \\
\text { that compromising } \\
\text { customers } \\
\text { requirement }\end{array}$ & $\begin{array}{l}\text { More business } \\
\text { prospect are on } \\
\text { positive track }\end{array}$ & $\begin{array}{l}\text { Company's } \\
\text { reputation , } \\
\text { business and } \\
\text { revenue } \\
\text { increasing }\end{array}$ \\
\hline
\end{tabular}

The Table 1 is able clearly define how this system is able to meet the organization expectation towards the revenue development happened to be the ultimate goal for ESD controls in industry which stated by author [11] and author [15].

\section{Conclusions}

This project is able to implement in semiconductor as this system meet the requirement of ANSI ESD S2020.2014 standard and the system able to detect the failure because it enters the production line. This will ensure the product are made is safe from ESDS events and confident during audits will be much higher and meets the global requirements as stated by ESDA.

\section{Recommendation}

The system is still addable to include another Electrostatic Control garments (smock) on its features so that in future this system can become one-point audit system for all Human Body voltage control in Electrostatic controls in semiconductor industries.

\section{Acknowledgement}

The authors would like to thank for the support given to this research to Universiti Teknologi Malaysia (UTM), grant Vot: Q.K130000.3556.06G45 


\section{References}

[1] Talebzadeh, Atieh, Mahdi Moradian, Yunan Han, David E. Swenson, and David Pommerenke. "Electrostatic charging caused by standing up from a chair and by garment removal." In 2015 IEEE Symposium on Electromagnetic Compatibility and Signal Integrity, pp. 57-62. IEEE, 2015. https://doi.org/10.1109/EMCSI.2015.7107659

[2] Somashekaraiah, C. M. "Overview of ESD impacts over industry yield: Technical consideration to control ESD during prototype development and production, advanced inspection techniques for ESD failure analysis." In 2016 International Conference on ElectroMagnetic Interference \& Compatibility (INCEMIC), pp. 1-4. IEEE, 2016. https://doi.org/10.1109/INCEMIC.2016.7921505

[3] Electrostatic Discharge Association, 2018

[4] Electrostatic Discharge Association, Compliance Verification of ESD Protective Equipment and Materials ESD TR5301-15

[5] Electrostatic Discharge Association, Floor Materials Characterization of Materials ANSI/ESD STM7.1-2013

[6] Electrostatic Discharge Association, Footwear/Flooring System - Voltage Measurement in Combination with a Person ANSI/ESD STM97.2-2016

[7] Huang, Yi-Jie, and Ming-Dou Ker. "Investigation of human-body-model and machine-model ESD robustness on stacked low-voltage field-oxide devices for high-voltage applications." IEEE Transactions on Electron Devices 63, no. 8 (2016): 3193-3198. https://doi.org/10.1109/TED.2016.2583380

[8] Vinson, James E., and Juin J. Liou. "Electrostatic discharge in semiconductor devices: protection techniques." Proceedings of the IEEE 88, no. 12 (2000): 1878-1902. https://doi.org/10.1109/5.899057

[9] Zhou, Jianchi, Kaustav Ghosh, Shaojie Xiang, Xin Yan, Ahmad Hosseinbeig, Jongsung Lee, and David Pommerenke. "Characterization of ESD risk for wearable devices." IEEE Transactions on Electromagnetic Compatibility 60, no. 5 (2018): 1313-1321. https://doi.org/10.1109/TEMC.2017.2780056

[10] Zhou, Jianchi, Kaustav Ghosh, Shaojie Xiang, Xin Yan, Ahmad Hosseinbeig, Jongsung Lee, and David Pommerenke. "Characterization of ESD risk for wearable devices." IEEE Transactions on Electromagnetic Compatibility 60, no. 5 (2018): 1313-1321. https://doi.org/10.1109/TEMC.2017.2780056

[11] Smallwood, Jeremy, Pasi Tamminen, and Toni Viheriaekoski. "Optimizing investment in ESD control." In Electrical Overstress/Electrostatic Discharge Symposium Proceedings 2014, pp. 1-6. IEEE, 2014.

[12] Lim, Steve, L. H. Koh, Muhammad Hamizan Bin Abdul Samad, W. F. Wong, and Y. H. Goh. "Product qualification \& degradation of steel toe ESD footwear." In 2016 38th Electrical Overstress/Electrostatic Discharge Symposium (EOS/ESD), pp. 1-7. IEEE, 2016. https://doi.org/10.1109/EOSESD.2016.7592532

[13] Namaguchi, Toshikazu, and Hideka Uchida. "Wrist strap designs and comparison of test results according to MILPRF-87893 and ANSI EOS/ESD association S1. 1." In Electrical Overstress/Electrostatic Discharge Symposium Proceedings. 1998 (Cat. No. 98TH8347), pp. 245-251. IEEE, 1998.

[14] Numaguchi, Toshikazu. "Actual static control market situation and how to choose suitable ESD flooring systems for ESD control working areas." In Electrical Overstress/Electrostatic Discharge Symposium Proceedings 2010, pp. 1-8. IEEE, 2010.

[15] Viheriäkoski, Toni, Jari Kohtamäki, Terttu Peltoniemi, and Pasi Tamminen. "Benchmarking of factory level ESD control." In 2015 37th Electrical Overstress/Electrostatic Discharge Symposium (EOS/ESD), pp. 1-7. IEEE, 2015. https://doi.org/10.1109/EOSESD.2015.7314769 